\title{
Marriage Breakdown in Estonia
}

\author{
DAGMAR KUTSAR
}

Research-Psychologist

Tartu University

The divorce rate is a statistical estimation of marriage breakdown in society. In Estonia, as a rule, it has been calculated from the number of marriages contracted the same year. More rarely a calculation concerning the entire population is used.

The number of divorces is the number of divorces registered at the Registrar's Offices. If a couple has no children or no disagreements to resolve, they are divorced there and their divorce is registered automatically. If a couple does have children and/or mutual disagreements, they have to go through a court process. Only after the registration of the divorce in the Registrar's Office is a marriage legally dissolved and both ex-spouses have the right to remarry. Many spouses who have gone through the divorce process in a court and resolved their disagreement do not register their divorce immediately. In these cases their divorce will be included in the divorce statistics of the year it is registered. Some people, who have no intentions or plans for remarrying, never register their divorce. In a situation like this, the divorce never reaches the divorce statistics.

Thus, the divorce rate of a certain year is an approximate indicator of marriage breakdown. This number does not include all the people who were divorced in the courts; it does not include persons who have separated and whose marriage has actually ended.

The aim of this article is to present divorce data for Estonia and to analyze the social processes and factors influencing marriage breakdown. This article mainly concentrates on the year 1988, when 5,924 divorces were registered in the municipal Registrar's Offices of Estonia.

The statistical data used comes from the Estonian Republican Registrar's Department, from Civil Censuses and from various collections of statistical data. Unfortunately our state statistics has been quite superficial. Without more detailed investigations we cannot draw deep conclusions about people who are getting divorced.

\section{Marriages, divorces and remarriages}

Divorce as a social problem in Estonian society gained in importance starting in the sixties, when a rapid increase in the divorce rate was noted.

From the sixties the number of divorces formed about one third of all marriages contracted the same year. The rapid increase in the divorce rate reached its peak in 1984, when the number of divorces formed already about one-half of the number of marriages contracted this year. During the last three years the divorce rate has stabilized at quite a high level, or at $45-47 \%$ (Table 1 ).

The increase in the number of remarriages has been higher than the rise in the divorce rate. Remarriages are a typical urban phenomenon. For example, in Tallinn, the capital of the Estonian Republic, $58.5 \%$ of all marriages in 1988 were first mar- 
Table 1. Marriages, divorces and remarriages in Estonia.

$\begin{array}{ccccc}\text { Year } & \text { Marriages } & \begin{array}{c}\text { Divorces } \\ \text { per } 100 \\ \text { marriages }\end{array} & \begin{array}{c}\text { Divorces } \\ \text { per } 1000 \\ \text { inhabitants }\end{array} & \begin{array}{c}\text { Remarriage } \\ \text { rate }\end{array} \\ 1940 & 10,182 & 11.6 & & 9.5 \\ 1950 & 10,456 & 16.4 & & 13.5 \\ 1960 & 12,146 & 20.9 & 3.2 & 16.5 \\ 1970 & 12,373 & 35.4 & & 20.0 \\ 1975 & 12,443 & 38.9 & 4.1 & 21.3 \\ 1980 & 12,964 & 47.3 & 3.9 & 25.7 \\ 1984 & 12,530 & 49.4 & 3.8 & 28.9 \\ 1985 & 12,861 & 47.1 & & \end{array}$

Table 2. Births in Estonia.

$\begin{array}{ccccccc}\text { Year } & \text { All } & \begin{array}{c}\text { Number of births } \\ \text { Urban } \\ \text { areas }\end{array} & \begin{array}{c}\text { Rural } \\ \text { areas }\end{array} & \text { All } & \begin{array}{c}\text { of illegitimate births } \\ \text { Urban }\end{array} & \begin{array}{c}\text { Rural } \\ \text { areas }\end{array} \\ 1980 & 4,057 & 2,156 & 1,901 & 18.3 & 13.9 & 28.5 \\ 1985 & 4,897 & 2,808 & 2,091 & 20.7 & 16.8 & 30.0 \\ 1986 & 5,293 & 3,003 & 2,290 & 22.0 & 17.7 & 32.1 \\ 1988 & 5,788 & 3,342 & 2,446 & 23.1 & 19.2 & 32.1 \\ 1989 & 6,123 & 3,479 & 2,644 & 25.2 & 21.1 & 34.0\end{array}$

riages, but in a rural area, for example in the Vôru district, this percentage was 75.2, on the island Hiiumaa even $79.1 \%$.

The remarriage rate is high in regions where the divorce rate is high. It is a reflection of the more liberal social attitude toward the remarriage of the divorced and widowed.

When taking into account the fact that the number of first marriages is decreasing (Vikat 1989), one can conclude that divorce as a means of legal regulation of one's marital status does not mean the breakdown of marriage as a social institution but that the choice of spouse has failed.

The declining number of first marriages refers to the increase in the frequency of cohabitation. Cohabitation as an alternative to marriage or as a preparation period for one's marriage (trial marriage) has not been investigated in Estonia. The only approximate way to estimate the gaining importance of cohabitation in Estonian society is making an assessment with the help of data about births (Table 2).

Table 2 shows that for the last ten years the rate of illegitimate births has been comparatively high in Estonia, and it has increased about 5\% during this period. The illegitimate birth rate in the countryside is notably higher than in the cities. This big difference is due to more widespread cohabitation and to the higher number of single people in the countryside because of an unfavorable demographic situation.

Cohabitation is more widespread among Estonians than or her nationalities in Estonia. $36 \%$ of first children of Estonians were illegitimate in $1987 ; 38 \%$ had their first child during the first 7 months of marriage. Hence, $74 \%$ of first children were conceived out of wedlock (Katus 1990).

The conclusion can be drawn here that behind the apparent stabilization of the divorce rate, an increasing variability in family formation is taking place. 


\section{Variations in the divorce rate}

The divorce rate varies a great deal within Estonia. As a rule, it is higher in urban areas and lower in rural areas; it is higher in regions with high immigration rates (especially in the northeastern industrial region) and the lowest in the Estonian islands and other old Estonian areas with a low immigration and industrialization level (Figure 1).

The highly industrialized areas are the result of the all-union ideology of binding all the Soviet republics together economically. For this aim large enterprises have been established in Estonia needing much labor force - for building them and working there afterwards. Thus these enterprises have been great instigators of migration for Estonia. As a result, the share of non-Estonians increased from 25.4\% in 1959 to 48.5 in 1989 (Katus 1990).

\section{Length of marriages}

The formal length of marriage is the time between two registrations: of marriage and divorce in the Registrar's Office. In spite of quite approximate data about the breakdown of marriages, we can estimate their duration.

Table 3 ja Figure 2 demonstrate that the first four years of marriage are the most dangerous for the stability of the marriage. According to the data for $1988,32.4 \%$ of marriages ending in divorce in cities and $29.6 \%$ in the countryside lasted about four years. About one fourth of the marriages ending in divorce had lasted 5-9 years. $59.2 \%$ of the divorced in the cities and $55.4 \%$ of those in the countryside were not able to celebrate the tenth anniversary of their marriage.

The high percentage of the divorced whose marriage lasted about 4 years points to weaknesses in our society; it hints of insufficient family education and family counseling, but it also reflects the economical difficulties that the young couple has to meet.

Family education has been provided only during the last ten years to the pupils in the last two grades of secondary school, and not in all schools. The problem is

Figure 1. The variations in divorce rate in Estonia in 1988.

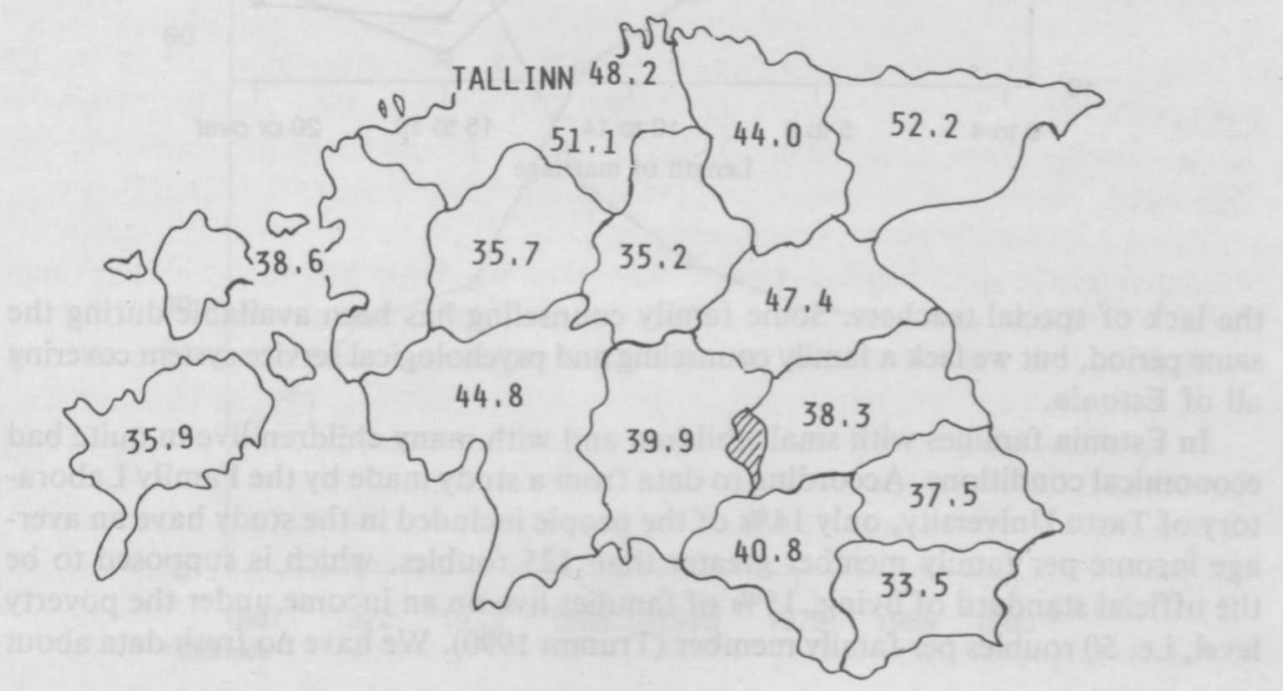


Table 3. Length of marriages ending in divorce in 1988.

\begin{tabular}{|c|c|c|c|c|c|c|}
\hline \multirow{2}{*}{ Years } & \multicolumn{3}{|c|}{ Urban areas } & \multicolumn{3}{|c|}{ Rural areas } \\
\hline & Number & $\%$ & Cumulative $\%$ & Number & $\%$ & Cumulative $\%$ \\
\hline$<1$ & 172 & 3.1 & 3.1 & 11 & 2.8 & 2.8 \\
\hline 1 & 358 & 6.5 & 9.6 & 17 & 4.3 & 7.1 \\
\hline 2 & 433 & 7.8 & 17.4 & 38 & 9.5 & 16.6 \\
\hline 3 & 431 & 7.8 & 25.2 & 28 & 7.0 & 23.6 \\
\hline 4 & 398 & 7.2 & 32.4 & 24 & 6.0 & 29.6 \\
\hline $5-9$ & 1,483 & 26.8 & 59.2 & 103 & 25.8 & 55.4 \\
\hline $10-14$ & 916 & 16.6 & 75.8 & 80 & 20.1 & 75.5 \\
\hline $15-19$ & 600 & 10.9 & 86.7 & 48 & 12.0 & 87.5 \\
\hline $20<$ & 734 & 13.3 & 100.0 & 50 & 12.5 & 100.0 \\
\hline All & 5,525 & & & 399 & & \\
\hline
\end{tabular}

Figure 2. Length of marriages divorced in 1988.

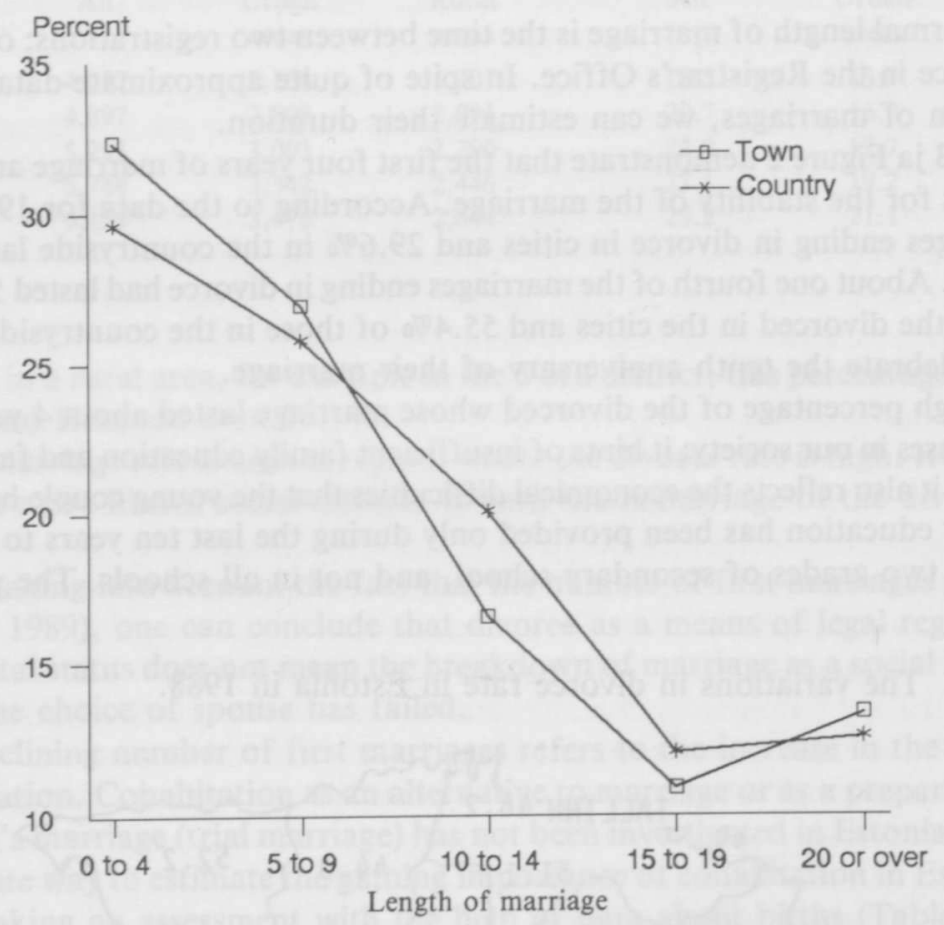

the lack of special teachers. Some family counseling has been available during the same period, but we lack a family counseling and psychological service system covering all of Estonia.

In Estonia families with small children and with many children live in quite bad economical conditions. According to data from a study made by the Family Laboratory of Tartu University, only $14 \%$ of the people included in the study have an average income per family member greater than 125 roubles, which is supposed to be the official standard of living, $15 \%$ of families live on an income under the poverty level, i.e. 50 roubles per family member (Trumm 1990). We have no fresh data about 
the changed economical situation of families after the price increase, regulation of salaries and the new subsidy system inaugurated in October-November 1990 .

Before 1989 maternity leave lasted only 1.5 years and after that a mother had to go back to work and most children attended preschool childcare institutions. The frequent illnesses of children depressed the whole family atmosphere. Starting in 1989 maternity leave was lengthened to three years and from the autumn of 1990 the mother has been entitled to an allowance during the entire leave, although unfortunately a very low one (see also Tiit 1990a).

The average length of marriage in towns was 6.6 years and in rural areas 7.5 years in 1988. In the country divorces occur less rapidly than in towns.

Compared to urban areas Estonian rural areas have preserved more social control over the people and neighborhood relations, which supports family stability. In rural areas, people more often have their own households, domestic animals and allotment gardens, all of which create common tasks and responsibilities and do not allow the couple to alienate themselves psychologically from one another. The rural way of life creates more barriers to the breaking up of marriage.

Unfortunately, nowadays Estonia is a highly urbanized country. In 1989 the urban population made up $71.6 \%$ of the whole population (Figure 3 ). A remarkable increase in the density of the population (Table 4) influences the relationships between people.

Figure 3. Urbanization in Estonia (Data of censuses).

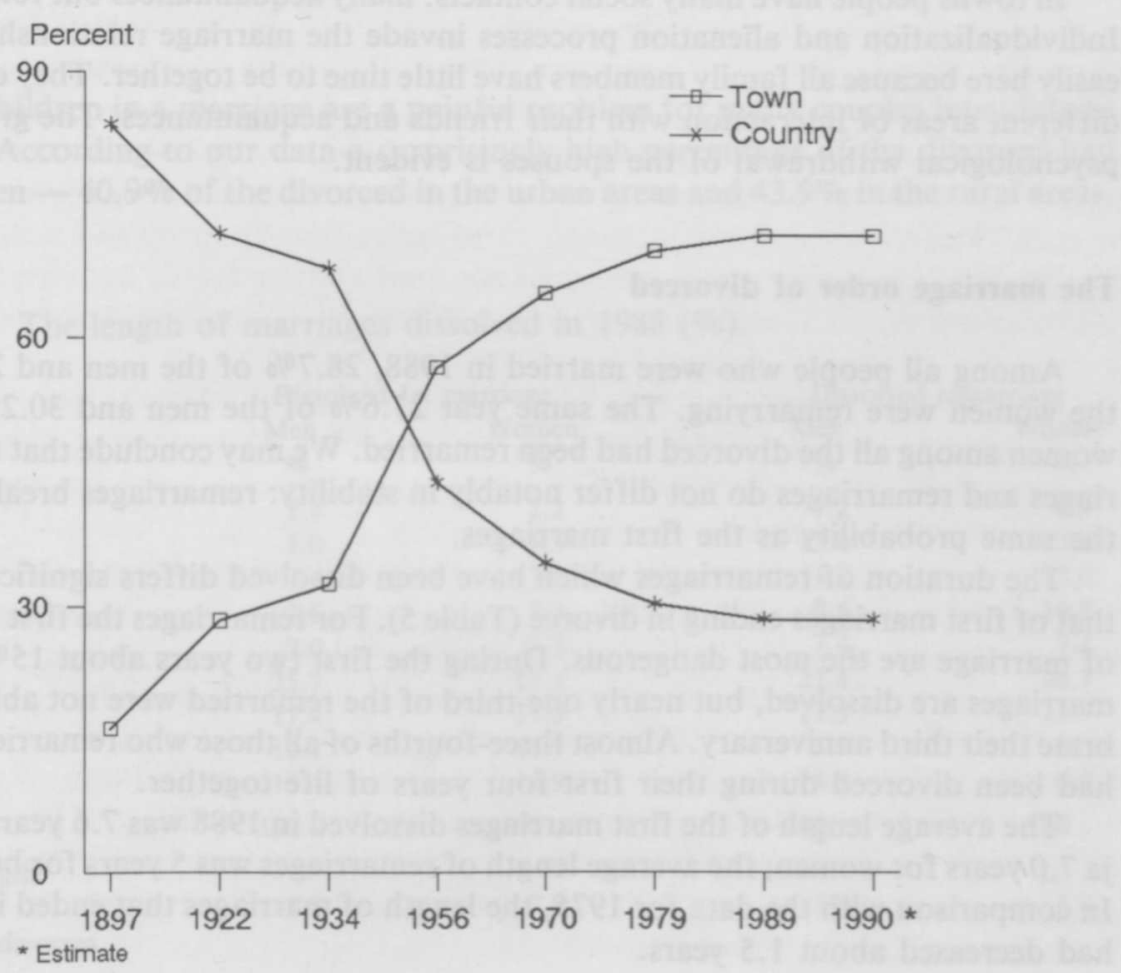


Table 4. Urbanization in Estonia (data census).

$\begin{array}{lcccc}\text { Year } & \begin{array}{c}\text { Whole population } \\ \text { in thousands }\end{array} & \begin{array}{c}\text { Percentage of population } \\ \text { Urban areas }\end{array} & \begin{array}{c}\text { Density } \\ \text { Rural areas }\end{array} & \begin{array}{c}\text { per square km } \\ 1897\end{array} \\ 1922 & 975 & 16.1 & 83.9 & 21.6 \\ 1934 & 1,044.1 & 28.5 & 71.5 & 23.1 \\ 1959 & 1,061.3 & 32.3 & 67.7 & 23.5 \\ 1970 & 1,196.8 & 56.4 & 43.6 & 26.5 \\ 1979 & 1,356.1 & 65.0 & 35.0 & 30.0 \\ 1989 & 1,465.8 & 69.7 & 30.3 & 32.5 \\ 1990^{*} & 1,572.9 & 71.6 & 28.4 & 34.9 \\ *-\text { estimate } & 1,582.8 & 71.6 & 28.4 & 35.1\end{array}$

In accordance with Soviet ideology, the aim was to eliminate differences between urban and rural areas. For this reason many small villages lost their inhabitants or only elderly people stayed there; the population moved to towns, town-like boroughs and the centers of collective and state farms. A town-like lifestyle in the centers of the collective and state farms has led to some undesirable features of urbanized society. Here these features became damaging: the possibility to hurt another person is much higher in a rural area because people know each other and their problems too well.

Life in towns and cities creates personalities without roots. About one fifth of the Estonian people live in their own houses, the most common dwelling is a flat rented from the state or an organization. A flat is not regarded as a home, but only as a place to live in. Life flows with hopes of moving into a more spacious flat. Therefore, families in towns in their rented flats have little to do with each other. Here lies hidden a lack in creating mutual responsibility and common tasks.

In towns people have many social contacts: many acquaintances but few friends. Individualization and alienation processes invade the marriage relationships more easily here because all family members have little time to be together. They even have different areas of interaction with their friends and acquaintances. The ground for psychological withdrawal of the spouses is evident.

\section{The marriage order of divorced}

Among all people who were married in $1988,28.7 \%$ of the men and $28.5 \%$ of the women were remarrying. The same year $27.6 \%$ of the men and $30.2 \%$ of the women among all the divorced had been remarried. We may conclude that first marriages and remarriages do not differ notably in stability: remarriages break up with the same probability as the first marriages.

The duration of remarriages which have been dissolved differs significally from that of first marriages ending in divorce (Table 5). For remarriages the first two years of marriage are the most dangerous. During the first two years about $15 \%$ of first marriages are dissolved, but nearly one-third of the remarried were not able to celebrate their third anniversary. Almost three-fourths of all those who remarried in 1988 had been divorced during their first four years of life together.

The average length of the first marriages dissolved in 1988 was 7.6 years for men ja 7.0 years for women; the average length of remarriages was 5 years for both sexes. In comparison with the data for 1975 , the length of marriages that ended in divorce had decreased about 1.5 years. 
The fact that dissolved remarriages are shorter results from the special features of remarriages. People who remarry have problems different from those of their first marriage: there are problems connected with the previous marriage, ex-spouse, children, etc. Remarrying people are, as a rule, older than people who marry for the first time. They have their own previous experiences of being married that influence the remarital relationship. Some previously divorced people have personality features not suitable for marital life. And finally, previously divorced people have experienced the break up of their marriage which decreases their subjective barrier toward divorce.

\section{The national homogeneity of the divorced}

In Estonia the two major national groups are Estonians and Russians, with Estonians forming the original nation. In the course of increase in national heterogeneity, nationally heterogeneous marriages have become more frequent. However, it is worth mentioning that national homogeneity has remained at quite a high level. In $198876.7 \%$ of all marriages concluded were nationally homogeneous (Table 6). The national homogeneity of Estonians was $84 \%$, of Russians $57 \%$. Russians form mixed marriages with Estonians more often than Estonians with Russians.

The next preferred nationality for Estonians was the Finns. In 1988171 marriages were contracted where one of the spouses was a Finn.

An increase in nationally mixed marriages of Estonians and Finns and, at the same time a decrease in marriages between Estonians and Russians is to be expected.

Among the divorced the national homogeneity of the two major national groups is higher than among those married during the same year.

\section{Children}

The children in a marriage are a painful problem for many couples intending to divorce. According to our data a surprisingly high percentage of the divorced had no children $-40.9 \%$ of the divorced in the urban areas and $43.9 \%$ in the rural areas.

Table 5. The length of marriages dissolved in $1988(\%)$.

Length of

marriage

(years)

$<1$

1

2

3

4

$5-9$

$10-14$

$15-19$

$20<$
7.6

of marriage

$\mathrm{N}-5,924$ divorces

7.0

$\begin{array}{cccc}\begin{array}{c}\text { Dissolved 1st marriage } \\ \text { Men }\end{array} & \begin{array}{c}\text { Domen } \\ \%\end{array} & \begin{array}{c}\text { Den } \\ \text { Wen }\end{array} & \begin{array}{c}\text { Women } \\ \%\end{array} \\ 2.4 & 2.2 & 7.2 & 6.9 \\ 5.0 & 5.3 & 13.0 & 12.3 \\ 7.4 & 7.2 & 11.2 & 12.0 \\ 7.6 & 7.2 & 9.6 & 10.2 \\ 7.0 & 7.3 & 7.4 & 7.4 \\ 25.7 & 27.1 & 27.4 & 26.3 \\ 17.4 & 17.0 & 13.5 & 13.7 \\ 12.1 & 11.7 & 5.9 & 6.3 \\ 15.4 & 14.9 & 4.8 & 4.9 \\ 100 & 100 & 100 & 100\end{array}$

5.0

5.0 
Table 6. National homogeneity of the divorced in 1988.

\begin{tabular}{lcccc} 
Nationality & Men & All & Women & \multicolumn{2}{c}{$\begin{array}{c}\text { Spouses of the same nationality } \\
\text { Men(\%) }\end{array}$} \\
Estonian & 2,670 & 2,705 & 88.8 & 87.7 \\
Russian & 2,466 & 2,550 & 76.7 & 74.2
\end{tabular}

Table 7. Women's labor participation (\%).

$\begin{array}{lccccccc}\text { Year } & 1940 & 1960 & 1970 & 1975 & 1980 & 1985 & 1987 \\ \% & 35 & 50 & 53 & 54 & 54 & 55 & 54\end{array}$

$19.4 \%$ of divorces confirmed in the Registrar's Offices (couples without children) and another $20 \%$ without children through the courts. According to official court statistics, in 1988 in all Estonian courts 4,807 marriages ended in divorce. Of these $924(19.2 \%)$ had no common children.

Moreover, Table 5 shows that in 1988 during the first four years of marriage about one third of all first marriages were dissolved. Among remarriages this share was significantly higher; among them are many childless couples. Unfortunately we have no data concerning this.

\section{Women and divorce}

In Estonia divorce is very often initiated by the wife. In 1988 only $18 \%$ had common applications for divorce; more than $75 \%$ of all divorces were initiated by women.

One reason for this has been the stress on the legal equality of men and women in the Soviet Union, while the higher educational level and social activity of women in the Soviet society developed a comparably independent and emancipated type of woman. Sometimes even the problems of so-called over-emancipated women exist. An extreme type is the woman who does not need a whole family but only children. Her husband loses his importance after the realization of the planned number of children in the family.

According to the data for 1985 (Väike Statistikakogumik 1989) the share of women in the labor force was $54.8 \%$. Estonian men work for an average of 32 years, but women for 36 years (Tiit 1990b). The employment rate of women has remained at its peak already for at least 20 years in Estonia (Table 7).

Moreover, women in Estonia make up $44.6 \%$ of leading workers and $73.6 \%$ of all kinds of specialists, $35.8 \%$ of the body of the Supreme Council and $49 \%$ of the bodies of local councils (Väike Statistikakogumik 1989).

Quite good possibilities for combining bringing up children and professional employment exist for women: $76 \%$ of children in urban areas and $50 \%$ in rural areas were guaranteed a place in day care (Väike Statistikakogumik 1989).

This high level of women's emancipation has been forced by the Soviet system where both sexes have to participate in society equally. As a result, Soviet women achieved much economic and psychological independence as well as self-awareness for resolving family crisis situations. 
Table 8 shows that nearly three fourths of all women whose divorce was registered in 1988 were under 40 years of age. These are women of fertile age with every possibility to contract a remarriage, form a new family and make a career. The high divorce frequency has created a liberal social attitude towards the divorced which will give them the opportunity to remarry.

In 19885,924 women divorced, $74.5 \%$ of them were in the labor force. Over threefourths were of fertile age. Obviously a great number of those outside the labor force were not all full-time mothers but were on maternity leave. Unfortunately we have no data on how many divorced women in 1988 had an under 3-year-old child at home.

Table 9 indicates that the higher the education level among women is, the higher is the labor participation rate. Higher orientation to work among women coincides with higher education.

\section{Discussion}

Estonia has been a country with a high divorce rate from the 1960 s, when a noticeable increase in the number of divorces began. The main social reasons for the increasing divorce rate have been rapid urbanization and industrialization, a high women's employment rate, an imbalance in family functions due to the low economical level of society.

The current situation in the Estonian Republic is unique. Estonia is fighting for her political and economical independence. The whole Estonian society is going through a reformation. This is a period when people need support from their fami-

Table 8. Women's age at divorce in 1988.

$\begin{array}{lcc}\text { Age at divorce } & \text { Number } & \text { Cumulative } \% \\ <20 & 54 & 0.9 \\ 20-24 & 840 & 15.1 \\ 25-29 & 1.350 & 38.0 \\ 30-34 & 1.186 & 58.1 \\ 35-39 & 923 & 73.7 \\ 40-44 & 564 & 83.3 \\ 45-49 & 412 & 90.3 \\ 50-54 & 272 & 94.9 \\ 55-59 & 152 & 97.5 \\ 60< & 149 & 100.0\end{array}$

$\mathrm{N}=5,902$

Table 9. Occupation and education of divorced women in 1988.

$\begin{array}{lrcccc}\text { Education } & \text { All } & \% & \begin{array}{c}\text { Working } \\ \%\end{array} & \begin{array}{c}\text { Mental } \\ \text { work (\%) }\end{array} & \begin{array}{r}\text { Physical } \\ \text { work (\%) }\end{array} \\ \text { Higher } & 805 & 13.6 & 92.6 & 89.6 & 10.4 \\ \text { Secondary professional } & 1,456 & 24.6 & 90.5 & 55.5 & 44.5 \\ \text { Secondary } & 2,027 & 34.2 & 85.3 & 31.8 & 68.2 \\ \text { Secondary uncompleted } & 511 & 8.6 & 82.4 & 10.0 & 90.0 \\ \text { Primary } & 333 & 5.6 & 67.0 & 4.9 & 95.1\end{array}$


lies to feel safe in a changing world. Such a situation binds the Estonian people together in order to reach common goals, such a situation binds family members together to meet and overcome new social problems.

On the other hand, the crisis in Estonian society is reflected in the family both economically and mentally, it creates new problems and destabilizes family relationships.

What might be the perspectives for Estonian marriages?

1. A continuous rise in age at first marriage is to be expected. Young people will be more oriented to the economical security of their own marriages. Many young singles will move abroad to study or work for some time and they will not marry until after returning. Cohabitation will increase among young persons and among the divorced and widowed.

2. The national homogeneity of Estonian marriages will rise on account of a decrease in marriages between Russians and Estonians.

3. The length of marriages which will end in a divorce will shorten as a consequence of the continuing social crisis: many people will not be able to adjust to a new economy and will suffer from the problems of security; sexual liberation will deepen the moral crisis in society.

4. Social and family policy will impose special importance on building up the welfare of families.

In conclusion, a noticeable increase or decrease in the divorce rate in Estonia is not to be expected. It will still remain at quite a high level.

\section{References}

Eesti arvudes 1989 aastal (1990). Lühike statistika kogumik. Tallinn.

Eesti NSV rahvamajandus. Statistika aastaraamat 1988 (1989). Tallinn.

Katus, Kalev (1990). Demographic trends in Estonia throughout the centuries. Yearbook of Population Research in Finland 28: 50-66.

Tiit, Ene (1990a). Family policy in the Estonian SSR, 1940-1989. In: Family Situation and Family Policy. Family Problems VIII, pp. 15-27.

Tiit, Ene (1990b). The status of woman in society and the family. Paper prepared for the scientific conference »The Baltic Family» held in Kaunas (Lithuania), 16-20 October 1990.

Trumm, A. (1990). The living conditions and income of the Estonian family. In: Estonian Population and the Family. Family Problems X, pp. 43-59.

Vikat, Andres (1989). Formation of Families. Population Studies. No. 11. Series B, Working Papers. Tallinn: Estonian Interuniversitary Population Research Centre.

Väike statistikakogumik (1989). Tallinn. 